\title{
Factors influencing Sudanese food habits in Britain
}

\section{By J. Al-Moкhalalati, Department of Nutrition, Queen Elizabeth College, University of London, Campden Hill, London $W^{7}{ }_{7} A H$}

A great deal of information is available about social, economic and political factors that can affect people's food choice but little research has been done on the effects of new cultural environments on migrants' food habits. Those studies which have been conducted on immigrants in Britain have concentrated mainly on people under stress or with serious health problems, whereas little is known about normal healthy people.

In view of this position, the present work was undertaken to identify and assess the factors which determine the food patterns of healthy people who have voluntarily moved into new conditions with different prevailing food habits from their own.

\section{METHODS}

The survey population included all Sudanese students who were staying in Britain for training or studying purposes. Wives were also included if resident in Britain. A structured questionnaire was designed to evaluate the changes in food habits of these students while they were staying in Britain. Information on preference for non-traditional foods, factors which might encourage or discourage the changing of their food habits and their attitude towards some foods were sought.

The questionnaires were intended for self-completion and were sent by post, a stamped addressed envelope for the respondent's reply was also provided. A total of $85^{2}$ individuals were approached, from whom $4 \mathrm{I} 5$ usable questionnaires were received.

The majority of the respondents were males $(80 \%)$, and $90 \%$ of them were Muslims. Most of the students were single $(56 \%)$, the rest were accompanied by their spouses. The average length of stay in the UK was 23 months and the average age of respondents was 28 years.

Those who were aged 24 years or less were considered to be 'young' and those who were $3^{1}$ years or more were considered to be 'old'. The respondents who were staying for $\mathrm{I} 2$ months or less were considered as 'short stay' (SS) and those who had spent 19 months or more were classified as 'long stay' (LS).

\section{RESULTS}

To identify and assess the factors which determine the food patterns of the Sudanese students in this new cultural environment, the respondents were asked firstly whether or not they had changed their food habits. Out of 404 respondents 
the majority ( $59 \%$ ) had changed their food habits, $38 \%$ indicated 'no change' and $3 \%$ did not know.

Cross tabulation analysis was used to investigate the relationship between the respondents' characteristics and behaviour.

Marital status and length of stay in Britain were expected to have major effects on changing dietary habits. Tables $I$ and 2 illustrate the classical approach to 'elaboration analysis' to see the effects of these independent variables on changing food habits.

The following points can be extracted from the tables: ( 1 ) among the SS group, although the difference between the single and married groups was not significant, a dissimilarity of their habits was observed; $78 \%$ of singles admit that they had changed their food habits $v .62 \%$ of the married group (Table I); (2) marital status had a direct effect on changing food habits in the LS group (Table I); (3) in spite of the difference between married SS $(62 \%)$ and LS (43\%) group members, length

Table I. Association between marital status and changing food habits (controlling length of stay)

(Percentages given in parentheses)

\begin{tabular}{|c|c|c|c|c|c|}
\hline & $\begin{array}{l}\text { Marital } \\
\text { status }\end{array}$ & Changed & No change & $\begin{array}{c}\text { No. } \\
\text { of cases }\end{array}$ & $\begin{array}{c}\text { Statistical } \\
\text { significance of } \\
\text { difference: } P\end{array}$ \\
\hline Short stay & $\begin{array}{c}\text { Married } \\
\text { Single } \\
\text { No. of cases }\end{array}$ & $\begin{array}{l}2 \text { I }(6 \mathrm{r} \cdot 8) \\
53(77 \cdot 9) \\
74\end{array}$ & $\begin{array}{l}13(38 \cdot 2) \\
15(22 \cdot 1) \\
28\end{array}$ & $\begin{array}{l}34(100 \cdot 0) \\
68(100 \cdot 0) \\
102\end{array}$ & NS \\
\hline Long stay & $\begin{array}{l}\text { Married } \\
\text { Single } \\
\text { No. of cases }\end{array}$ & $\begin{array}{r}4^{2}(42 \cdot 9) \\
74(74 \cdot 7) \\
\text { I } 66\end{array}$ & $\begin{array}{l}5^{6}(57 \cdot 1) \\
25(25 \cdot 3) \\
81\end{array}$ & $\begin{array}{l}98(100 \cdot 0) \\
99(100 \cdot 0) \\
197\end{array}$ & 0.001 \\
\hline
\end{tabular}

Table 2. Association between length of stay and changing food habits (controlling marital status)

(Percentages given in parentheses)

$\begin{array}{llcccc}\text { Length } & \begin{array}{c}\text { No. } \\ \text { of stay }\end{array} & \text { Changed } & \text { No change } & \begin{array}{c}\text { Statistical } \\ \text { of cases } \\ \text { significance of } \\ \text { difference }\end{array} \\ & \text { Short } & 21(61 \cdot 8) & 13(38 \cdot 2) & 34(100 \cdot 0) & \\ \text { Single } & \text { Long } & 42(42 \cdot 9) & 56(57 \cdot 1) & 98(100 \cdot 0) & \text { NS } \\ & \text { No. of cases } & 63 & 69 & 132 & \\ & \text { Short } & 53(77 \cdot 9) & 15(22 \cdot 1) & 68(100 \cdot 0) & \\ & \text { Long } & 74(74 \cdot 7) & 25(25 \cdot 3) & 99(100 \cdot 0) & \text { NS } \\ & \text { No. of cases } & 127 & 40 & 167 & \end{array}$

NS, not significant. 
of stay seems to have had no statistically significant effect on changing food habits (Table 2); (4) regarding single respondents (Table 2), it is of interest to note that $78 \%$ of the SS group stated that they had changed their food habits compared with $75 \%$ of the LS group. This means that the length of stay had no effect on changing food habits, not only among the married group but also among the single group.

More information was obtained from those who stated that their diet had changed. Three reasons were suggested to explain the respondents' shift away from their traditional diet. More married respondents considered the unavailability of Sudanese foods as a reason for altering their dietary customs whereas the comment from single subjects that ' $I$ have no time to cook' was more frequently given. It was found that the cost of food had little effect on food habits, being mentioned infrequently by both married and single groups.

\section{DISCUSSION}

Marital status. The initial expectation that single respondents would be more likely to change their food habits than married respondents seems to be valid; especially if they had lived in Britain for a long time. Among the short stay group the insignificant difference (Table I) might be explained in two possible ways. Firstly whether they were married or single, subjects bought and ate whatever was available to them at the beginning of their stay in Britain. Second, the married SS group may not have had adequate facilities for cooking their traditional dishes. In fact Yang \& Fox (1979) found in a study of food habits of Chinese persons living in the United States that single persons are likely to change their food habits more than married persons. In their study they found that adaptation scores of people who ate with Chinese people every day tended to be lower than scores of respondents who ate alone.

Regarding married people, Arabic women find that food preparation is one of the most satisfactory ways of caring for the family, they might spend the whole day in the kitchen while their men are taking care of outdoor responsibilities. In Britain, as in the Sudan, the life-style of the married group is likely to be the same in the way that the length of time needed to prepare food is not an important factor, while single people are reluctant to devote the necessary time to cooking their usual dishes, as has been shown earlier. In addition, Sudanese women, who rarely eat outside their own society, get no opportunities to experience new foods or methods of preparation and consequently they will maintain their traditional way of eating. On the other hand the single group, separated from their families, are introduced to new foods (e.g. college lunch) and they may be encouraged to change their food habits since they have lost the privilege of eating what their mothers cooked for them.

Duration of visit to UK. The length of stay in Britain seemed to have no direct association with the respondents' food habits. However, among the married group, the proportion of those who changed to British food after a short stay was greater than that from the long stay group. The survey revealed that as they stayed longer 
they adhered more strongly to their ethnic food habits. This attitude might be due to the possibility that they might have become more aware of Asian food shops, where most of their traditional food could be bought. In addition, there is the possibility that better accommodation might have been found, where the cooking facilities were more adequate. This finding agrees with a study of West Indian immigrants (McKenzie \& Mumford, 1964), where strong adherence to West Indian foods was found even amongst those who had lived in Britain for more than five years.

Food price. This had no real effect on the respondents' food habits despite the observation that traditional food prices are relatively higher in Britain than at home. This might be explained on the grounds that the level of income of students in this country is much better than in the Sudan. McKenzie (1964) pointed out that with rising incomes and the declining significance of the cost of food in the total budget, it was likely that price would not greatly influence food choice. The other explanation might be that, since the most desirable foods such as meat, eggs and fruits are much cheaper in Britain than in the Sudan, the lower prices of some items might compensate for the extra amount of money which the immigrants usually pay to buy their traditional foods. Thus they might maintain the same frequency of eating their traditional food, as long as it was available.

In conclusion, it is clear that eating of non-traditional foods by individuals is a complex reaction involving social, cultural and environmental factors. However, several provocative questions remain to be answered. For example, what is the importance of food preparation time in the maintenance or decline of an ethnic diet? To what extent have the Sudanese (who indicated that they change their food habits) already adopted European food patterns in their homelands and what is the relationship between dietary adaptation and other types of adjustments?

REFERENCES

McKenzie, J. C. (1964). In Changing Food Habits [J. Yudkin and J. C. McKenzie, editors]. London: McGibbon \& Kee.

McKenzie, J. C. \& Mumford, P. (1964). Proc. Nutr. Soc. 23, XIII.

Yang, G. I. P. \& Fox, H. M. (I 979). F. Am. Diet. Ass. 75, 420. 